University of Nebraska - Lincoln

DigitalCommons@University of Nebraska - Lincoln

\title{
Performance and Digestibility Characteristics of Finishing Diets Containing Distillers Grains, Composites of Corn Processing Coproducts, or Supplemental Corn Oil
}

\author{
K. J. Vander Pol \\ University of Nebraska-Lincoln \\ Matt K. Luebbe \\ University of Nebraska - Lincoln, mluebbe2@unl.edu \\ G. I. Crawford \\ University of Nebraska - Lincoln \\ Galen E. Erickson \\ University of Nebraska-Lincoln, gerickson4@unl.edu \\ Terry J. Klopfenstein \\ University of Nebraska-Lincoln, tklopfenstein1@unl.edu
}

Follow this and additional works at: https://digitalcommons.unl.edu/animalscifacpub

Part of the Animal Sciences Commons

Vander Pol, K. J.; Luebbe, Matt K.; Crawford, G. I.; Erickson, Galen E.; and Klopfenstein, Terry J., "Performance and Digestibility Characteristics of Finishing Diets Containing Distillers Grains, Composites of Corn Processing Coproducts, or Supplemental Corn Oil" (2009). Faculty Papers and Publications in Animal Science. 474.

https://digitalcommons.unl.edu/animalscifacpub/474

This Article is brought to you for free and open access by the Animal Science Department at DigitalCommons@University of Nebraska - Lincoln. It has been accepted for inclusion in Faculty Papers and Publications in Animal Science by an authorized administrator of DigitalCommons@University of Nebraska - Lincoln. 
(C) 2008 American Society of Animal Science. Used by permission.

Running head: Distillers grains components

\section{Performance and digestibility characteristics of finishing diets containing distillers grains, composites of corn processing coproducts, or supplemental corn oil ${ }^{1}$}

K. J. Vander $\mathrm{Pol}^{2}$, M. K. Luebbe, G. I. Crawford, G. E. Erickson ${ }^{3}$, and T. J. Klopfenstein Department of Animal Science, University of Nebraska, Lincoln, NE 68583-0908

\footnotetext{
${ }^{1}$ A contribution of the University of Nebraska Agricultural Research Division, supported in part by funds provided through the Hatch Act.

${ }^{2}$ Present address: Koers-Turgeon Consulting; 2000 Ridgeview Rd; Salina, KS 67401

${ }^{3}$ Corresponding author: geericks@unlnotes.unl.edu
} 
ABSTRACT: Three experiments evaluated the lipids in distillers grains plus solubles compared with corn or other sources of lipid in finishing diets. Experiment 1 utilized 60 individually fed yearling heifers $(349 \pm 34 \mathrm{~kg})$ fed treatments consisting of 0,20 , or $40 \%$ (DM basis) wet distillers grains plus solubles (WDGS), or 0, 2.5, or 5.0\% (DM basis) corn oil in a finishing diet based on high-moisture corn (HMC) and dry-rolled corn (DRC). Cattle fed 20 and 40\% WDGS had greater $(P<0.10) \mathrm{G}: \mathrm{F}$ than cattle fed 0\% WDGS. Cattle fed the 5.0\% corn oil had lower overall performance than cattle fed the other diets. Results from Exp. 1 indicated that adding fat from WDGS improves performance, whereas supplementing 5.0\% corn oil depressed G:F, suggesting that the fat within WDGS is different than corn oil. Experiment 2 used 234 yearling steers $(352 \pm 16 \mathrm{~kg})$ fed 1 of 5 treatments consisting of 20 or $40 \%$ (DM basis) dry distillers grains plus solubles (DDGS), $1.3 \%$ or $2.6 \%$ (DM basis) tallow, or HMC. All diets contained $20 \%$ (DM basis) wet corn gluten feed (WCGF) as a method of controlling acidosis. No differences between treatments for any performance parameters were observed in Exp. 2. The DDGS may be similar to tallow and HMC in finishing diets containing 20\% WCGF. Experiment 3 used 5 Holstein steers equipped with ruminal and duodenal cannulas in a $5 \times 5$ Latin square design. Treatments were a 40\% WDGS diet, 2 composites, one consisting of corn bran and corn gluten meal (COMP), and one consisting of corn bran, corn gluten meal, and corn oil (COMP + OIL), and 2 DRC-based diets supplemented with corn oil (CON + OIL) or not (CON). Cattle fed the WDGS diet had numerically lower rumen $\mathrm{pH}$ compared with cattle fed other treatments. Cattle fed WDGS had greater $(P<0.10)$ molar proportions of propionate, lower $(P<0.10)$ acetate:propionate ratios, greater $(P<0.10)$ total tract fat digestion, and a greater $(P<0.10)$ proportion of unsaturated fatty acids reaching the duodenum than cattle fed other treatments. Therefore, the higher energy value of WDGS compared with corn may be due to more 
propionate production, higher fat digestibility, and more unsaturated fatty acids reaching the duodenum.

Key Words: Digestibility, Distillers grains plus solubles, Fat, Finishing cattle

\section{INTRODUCTION}

The increasing supply of wet distillers grains plus solubles (WDGS) has increased usage for finishing cattle. The higher energy value of WDGS compared with dry-rolled or highmoisture corn has been reported (Klopfenstein et al., 2008; Lodge et al., 1997a; Ham et al., 1994). Stock et al. (2000) suggested that the higher energy value of WDGS may be due to controlling subacute acidosis, higher fat content, or overall increased energy utilization. Lodge et al. (1997b) fed fat or protein with wet corn gluten feed (WCGF) to mimic distillers grains and observed that G:F was slightly reduced when either fat or protein were removed, which suggest fat contributes to the energy value of WDGS.

The fat content of WDGS is roughly 3 times that of the grain from which it was derived (Klopfenstein et al., 2008), with fat providing more energy than other nutrients (Zinn, 1994). Additionally, free unsaturated fatty acids that enter the rumen are subject to biohydrogenation (Russell, 2002), with duodenal flow of fatty acids being comprised mainly of saturated fat. Absorption of fatty acids is dependent on the formation of micelles, with unsaturated fatty acids forming micelles with a greater surface area, allowing more efficient utilization (Zinn et al., 2000). It is plausible that fat within WDGS may be partially protected from complete biohydrogenation, allowing an increased flow of unsaturated fatty acids to the duodenum, which can then be utilized by the animal more efficiently. 
The objectives of this research were to determine the effect of feeding WDGS or supplemental fat on performance and rumen metabolism and digestibility, with an aim of determining whether fat is responsible for the higher energy value of WDGS compared with corn in finishing diets.

\section{MATERIALS AND METHODS}

Animal care for these experiments complied with procedures approved by the University of Nebraska Institutional Animal Care and Use Committee.

\section{Experiment 1}

A 113-d finishing trial utilized 60 crossbred yearling heifers $(349 \pm 34 \mathrm{~kg})$ with British breed influences in a trial designed with a $2 \times 3$ factorial arrangement of treatments. Heifers were received at the University of Nebraska's Agricultural Research and Development Center (Ithaca, NE) in the fall of 2001. Upon arrival, heifers were weighed, vaccinated, and weaned on stockpiled smooth bromegrass pastures. After weaning, heifers were housed in an open-front barn and trained to use Calan gates (American Calan Inc., Northwood, NH). Prior to this trial, heifers were utilized in two 84-d growing trials. Heifers were weighed for 3 consecutive days prior to the initiation of the trial while being limit-fed (2.0\% of BW daily) a high-fiber diet consisting of (DM basis) 50\% alfalfa hay and 50\% wet corn gluten feed (WCGF) to obtain an accurate initial weight. Heifers were stratified by BW and assigned randomly to treatment. Individual heifer was the experimental unit and there were 10 replications per treatment.

Factors consisted of source (corn oil or WDGS) and level of fat. Dietary treatments (Table 1$)$ were $0 \%$ corn oil (0FAT), $2.5 \%$ corn oil (2.5FAT), 5.0\% corn oil (5FAT), 0\% WDGS (0DG), 20\% WDGS (20DG), or 40\% WDGS (40DG). Alfalfa hay was included in all diets at 
$7.5 \%$ of diet DM, and high-moisture corn (HMC) and dry-rolled corn (DRC) were fed at a 1:1 ratio (DM basis). Corn oil or WDGS replaced corn. Diets were formulated such that the 2.5FAT and 20DG diets contained the same amount of ether extract (EE), and the 5FAT and 40DG diets contained the same amount of EE. All diets were formulated to meet or exceed degradable intake protein, MP, Ca, K, and P requirements of the heifers (NRC, 1996). All diets contained monensin (29.7 mg/kg DM; Elanco Animal Health, Indianapolis, IN), tylosin (11 mg/kg DM; Elanco Animal Health, Indianapolis, IN), and melengestrol acetate ( $0.5 \mathrm{mg} / \mathrm{d}$; Pfizer, New York, NY). Heifers were fed individually, once daily with the use of Calan gates (American Calan Inc., Northwood, NH) and were housed in a modified-open front barn with a gutter flush system. Dietary adaptation consisted of a limit-feeding procedure where the initial amount of the treatment diet offered was $5.5 \mathrm{~kg} / \mathrm{d} \mathrm{DM}(1.6 \%$ of BW), and daily DM allotments were increased $0.23 \mathrm{~kg} / \mathrm{d}$ (DM basis) until heifers reached ad libitum consumption (approximately $21 \mathrm{~d}$ ). Feed refusals were collected and weighed 3 times per week or at the discretion of the technician to obtain accurate estimates of DMI.

Heifers were weighed every 28 d, and were implanted on d 28 with Synovex-Plus (Fort Dodge Animal Health, Fort Dodge, IA). Diets were sampled twice monthly, frozen, freeze dried, ground, and analyzed for EE (AOAC, 1965).

Heifers were slaughtered on d 114 at a commercial abattoir (Tyson Fresh Meats, West Point, NE). Hot carcass weight and liver scores were recorded on day of slaughter. Longissimus muscle area and fat thickness were measured after a 24-h chill. Marbling score and yield grade were called by a trained USDA grader. Final BW, ADG, and G:F were calculated based on $\mathrm{HCW}$ adjusted to a common dressing percentage of $62 \%$ for heifers to minimize error associated with gut fill. 
The $\mathrm{NE}_{\mathrm{g}}$ of each diet was calculated with a spreadsheet requiring animal performance inputs (Owens et al., 2002). Net energy for gain equations used within the program were those outlined by NRC (1996) and Zinn (1989a). The NEg content of WDGS was calculated by substitution for high-moisture and dry-rolled corn equally, assuming that the individual basal ingredients possessed the same energy value across each diet.

Corn distillers grains and distillers solubles were produced at a commercial ethanol plant (Abengoa Bioenergy, York, NE). Distillers grains were delivered once weekly to the research facility. Samples were taken from each load and were subsequently analyzed for DM, frozen, freeze-dried, ground through a 1-mm screen, and analyzed for EE (AOAC, 1965). Distillers grains were stored in 208-L barrels, sealed, and refrigerated at $5^{\circ} \mathrm{C}$ until needed for feeding to prevent spoilage. Distillers solubles were received in 1 truck load and stored in liquid supplement tanks. Distillers solubles were sampled weekly to determine DM, and were sampled twice monthly, frozen, freeze-dried, ground through a 1-mm screen, and analyzed for EE (AOAC, 1965).

Distillers grains and distillers solubles were mixed daily to ensure that any responses due to consistency of the WDGS mix were minimized. Distillers grains and distillers solubles were fed at a 65:35 ratio (DM basis). This ratio was similar to that produced by the ethanol plant.

Data were analyzed using the Mixed procedure of SAS (Version 8.0, SAS Inst., Inc., Cary, NC) as a $2 \times 3$ factorial arrangement of treatments. Heifer was used as the experimental unit in all statistical evaluations. The model included source, level, and the interaction of source and level. If the interaction between source and level was not significant, then the main effects of source or level were analyzed. If the source by level interaction was significant, the simple effects of level within source were examined. Level effects, whether main or simple effects, were 
tested with orthogonal contrasts. Because the preceding trial was designed with 2 different programmed daily gains, previous ADG was used as a covariate in the model. Responses were considered significant at $P<0.10$.

\section{Experiment 2}

Two hundred thirty-four crossbred yearling steers $(352 \pm 16 \mathrm{~kg})$ were utilized in a trial with a $2 \times 2+1$ factorial arrangement of treatments. Factors consisted of fat source, either dry distillers grains plus solubles (DDGS) and tallow, and level of fat source $(0,1.3$, or $2.6 \%$ added fat). Dietary treatments (Table 2) consisted of 0\% tallow/0\% DDGS (CON), $1.3 \%$ tallow (1.3TAL), 2.6\% tallow (2.6TAL), 20\% DDGS (20DG), and 40\% DDGS (40DG), with tallow or DDGS replacing corn. Wet corn gluten feed (Sweet Bran, Cargill Corn Milling, Blair, NE), a byproduct of the corn wet-milling industry, was included in all diets at $20 \%$ of DM to minimize the factors associated with subacute acidosis. Additionally, corn silage and dry supplement were included in all diets at 10 and $3 \%$ of DM, respectively, with the balance of the diet consisting of HMC. The 1.3TAL and 20DG diets were formulated to provide the same of amount of dietary fat to the steers, as were the 2.6TAL and 40DG diets. All diets were formulated to meet the minimum requirements for DIP, MP, Ca, P, K, and trace minerals outlined by the NRC (1996). All diets contained monensin $(28.0 \mathrm{mg} / \mathrm{kg}$ DM; Elanco Animal Health, Indianapolis, IN), and tylosin (10.0 mg/kg DM; Elanco Animal Health, Indianapolis, IN). Dietary adaptation consisted of a procedure where HMC replaced corn silage. Treatments containing either tallow or DDGS contained those ingredients at their specified level at study initiation, and these feeds as well as $20 \%$ wet corn gluten feed were held constant throughout the adaptation and experiment. Corn silage was initially $60 \%$ of diet DM and was decreased to 46,34 , and $22 \%$ across 3,4 , 7, and $7 \mathrm{~d}$ until cattle reached the finishing ration ( $10 \%$ corn silage). With this adaptation scheme, it was 
only possible with the CON, 1.3TAL, and 2.6TAL diets to have $60 \%$ corn silage in the first adaptation diet. For cattle fed 20DG, 50\% corn silage was fed for the first adaptation diet, and then 46,34 , and $22 \%$ was fed during the remaining adaptation periods. Cattle fed 40DG were fed $37 \%$ corn silage during the first 2 adaptation periods and then 34 and $22 \%$ corn silage for the last 2 adaptation periods. Bunk reading was conducted daily at $0600 \mathrm{~h}$, and adjustments were made according to the quantity of feed estimated to be remaining in the bunk at time of feeding. The goal was that the last amount of feed would be consumed just prior to feeding. Steers were fed once daily at $0800 \mathrm{~h}$ by means of a single axle truck equipped with a Roto-Mix model 420 (RotoMix, Dodge City, KS) mixer/delivery box. Feed refusals were collected on each weigh date, or at the discretion of the unit manager, sampled, frozen, and analyzed for DM, to determine DMI.

Steers $(n=234)$ were received at the University of Nebraska's Agricultural Research and Development Center (Ithaca, NE) in the fall of 2001. Upon arrival, steers were weaned on smooth bromegrass pastures for approximately $21 \mathrm{~d}$. After weaning, steers grazed corn residue while being supplemented $2.27 \mathrm{~kg} / \mathrm{d}$ (DM basis) WCGF. After the conclusion of corn residue grazing (approximately $120 \mathrm{~d}$ ), steers were drylotted while being limit-fed a diet consisting of $50 \%$ WCGF and 50\% ground alfalfa hay (DM basis) at 2.0\% of BW daily for $30 \mathrm{~d}$. In late April 2002, steers returned to the cool season smooth bromegrass pastures where they grazed for approximately $30 \mathrm{~d}$. In early May, steers were hauled to a ranch in North-Central Nebraska where they grazed native Sandhills range until early September, when they were returned to the University of Nebraska's Agricultural Research and Development Center. After returning from the Sandhills, steers were drylotted and limit-fed the 50\% WCGF, 50\% alfalfa hay diet at 2.0\% of BW daily for $5 \mathrm{~d}$. Steers were weighed on 2 consecutive days before the initiation of the trial following the 5-d limit feeding period. Steers were stratified by BW and assigned randomly to 
pen (9 steers, rep 1; 10 steers, rep 2 through 4$)$, pen was assigned randomly to treatment with a total of 24 pens ( 4 pens for the TAL and DG diets and 8 pens for the CON diet).

Steers were implanted on d 21 with Revalor-S (Intervet, Millsboro, DE). Steers were slaughtered on d 120 at a commercial abattoir (Tyson Fresh Meats, West Point, NE). Carcass data were collected similarly to procedures outlined in Exp. 1. Final BW, ADG, and G:F were calculated based on $\mathrm{HCW}$ adjusted to a common dressing percentage of $63 \%$ for steers. The $\mathrm{NE}_{\mathrm{g}}$ values for the diets, as well as the DDGS were calculated similarly as described in Exp. 1. Data were analyzed using a protected $F$-test. Simple effects of linear and quadratic responses to fat from either DDGS or tallow were analyzed using contrasts as only 1 control treatment was used. Corn DDGS were produced at a commercial ethanol plant (Abengoa Bioenergy, York, NE) and were received at the research facility on an as-needed basis. Wet corn gluten feed was delivered to the research facility 3 times weekly and stored in an open commodity barn.

\section{Experiment 3}

From January 8, 2005 to April 23, 2005 (105 d), a metabolism experiment was conducted to evaluate the effects of feeding WDGS, a composite, or supplemental corn oil in finishing diets on various aspects of feeding behavior, digestion, duodenal fatty acid profile, and metabolism. The experiment utilized 5 Holstein steers that had been previously equipped with cannulas in the rumen and proximal duodenum in a row by column design set up as a balanced $5 \times 5$ Latin square experiment. Dietary treatments (Table 3) were 40\% WDGS (WDGS), a composite consisting of corn bran and corn gluten meal (COMP), a composite consisting of corn bran, corn gluten meal, and corn oil (COMP + OIL), and 2 DRC-based high concentrate controls without $(\mathrm{CON})$ and with corn oil $(\mathrm{CON}+\mathrm{OIL})$. The COMP diet was formulated to be equal in NDF and $\mathrm{CP}$ to the WDGS diet. The COMP + OIL diet was formulated to be equal in NDF, CP, and EE 
to the WDGS diet. The CON + OIL diet was formulated to be equal in EE to the WDGS diet. The remainder of the WDGS diet consisted of DRC, alfalfa hay, and dry supplement. The remainder of the other dietary treatments consisted of DRC, alfalfa hay, dry supplement, and cane molasses. Dry-rolled corn was processed through a single roll roller-mill, and all kernels appeared to broken into thirds. All diets contained $33 \mathrm{mg} / \mathrm{kg}$ monensin (Elanco Animal Health, Indianapolis, IN) and $11 \mathrm{mg} / \mathrm{kg}$ tylosin (Elanco Animal Health, Indianapolis, IN). Three-week experimental periods allowed $16 \mathrm{~d}$ for adapting steers to experimental diets and $5 \mathrm{~d}$ for data collection. For d 1 through 16, steers were housed in individual 1.5 x 2.4 m slotted-floor pens with rubber mats in a temperature controlled room $\left(25^{\circ} \mathrm{C}\right)$ and ad libitum access to water. On $\mathrm{d}$ 17, steers were moved within the same room to tie stalls and tethered for continuous $\mathrm{pH}$ and intake measurements for the 5-d period.

Steers were fed once daily at $0700 \mathrm{~h}$ and were permitted ad libitum intake of experimental diets. Continual monitoring of DMI by steers was accomplished through use of feed bunks suspended on load cells (Omega, Stamford, CT) and connected to a computer with data acquisition software (Labtech, Wilmington, MA) that recorded bunk weight every minute over the entire feeding period and through weighing of orts. Data were obtained for continuously monitored DMI on d 17 through 21 of the collection period, and included daily intake, time spent eating, number of meals consumed, and average meal size. Feed ingredients were sampled weekly and composited by period, whereas feed refusals were sampled daily on d 17 through 21 and composited by period; all samples were stored frozen at $-20^{\circ} \mathrm{C}$. At the conclusion of each period, feed ingredients and feed refusal composites were freeze-dried and ground to pass through a 1-mm screen of a Wiley mill (Thomas Scientific, Swedesboro, NJ). 
Chromic oxide (Landers-Segal Color Co., Montvale, NJ) was dosed intraruminally twice daily to provide $15 \mathrm{~g} / \mathrm{d}$ on d 14 through 20 in order to estimate duodenal flow and fecal output.

Ruminal fluid samples were collected every $2 \mathrm{~h}$ on d 17 between 0700 and $1900 \mathrm{~h}$.

Samples were collected through the rumen cannula using the suction strainer technique (Raun and Burroughs, 1962). Approximately $50 \mathrm{~mL}$ were collected, which was immediately frozen at $20^{\circ} \mathrm{C}$ for later analysis. Ruminal VFA (acetate, propionate, butyrate, isobutyrate, valerate, and isovalerate) were measured using gas chromatography according to procedures outlined by Erwin et al. (1961).

Ruminal $\mathrm{pH}$ was measured continuously on $\mathrm{d} 18$ to 21 with submersible $\mathrm{pH}$ probes (Sensorex, Stanton, CA) fitted through the rumen cannula and suspended in rumen fluid. Rumen $\mathrm{pH}$ measurements were collected with software (Labtech, Wilmington, MA) with a reading taken every $6 \mathrm{~s}$ and averaged across every $1 \mathrm{~min}$ (1,440 measurements/d). Ruminal metabolism measurements included average ruminal $\mathrm{pH}$, maximum and minimum ruminal $\mathrm{pH}$, ruminal $\mathrm{pH}$ change (maximum minus minimum), ruminal $\mathrm{pH}$ variance, and ruminal $\mathrm{pH}$ area below 5.6. Average ruminal $\mathrm{pH}$ was calculated as the average of 1,440 measurements recorded daily. Ruminal pH variance and area below 5.6 were calculated as described by Cooper et al. (1999). Fecal samples (approximately 50 g) were collected at 0700, 1300, and $1900 \mathrm{~h}$ on d 17 through 20 . Fecal samples were composited by day and immediately frozen at $-20^{\circ} \mathrm{C}$. At the conclusion of each period, fecal composites were freeze-dried and ground to pass through a 1mm screen of a Wiley mill (Thomas Scientific, Swedesboro, NJ). After grinding, daily fecal composites were composited by period.

Duodenal samples (approximately $250 \mathrm{~mL}$ ) were collected at 1000, 1600, and $2200 \mathrm{~h}$ on d 20, and 0700,1300 , and $1900 \mathrm{~h}$ on d 21. Approximately $50 \mathrm{~mL}$ of each sample was 
immediately separated from initial sample and added to a composite at time of collection. Immediately after the collection, all samples were frozen at $-20^{\circ} \mathrm{C}$. After the conclusion of each period, duodenal composites as well as individual time point samples were freeze-dried and ground to pass through a 1-mm screen of a Wiley mill (Thomas Scientific, Swedesboro, NJ). Feed ingredient, feed refusal, duodenal, and fecal sample analysis included DM (AOAC, 1999; method 4.1.03), ash (AOAC, 1999; method 4.1.10), CP (AOAC, 1999; method 4.2.04) using a combustion-type N analyzer (Leco FP 528 Nitrogen Autoanalyzer, St. Joseph, MI), NDF (Van Soest et al., 1991) incorporating heat stable $\alpha$-amylase (Ankom Technology, Macedon, NY) at 1 mL per 100 mL of NDF solution (Midland Scientific, Omaha, NE), total starch (AOAC, 1999; method 996.11) utilizing a commercially available total starch assay procedure kit (Megazyme, Wicklow, Ireland), and EE or fat (Folch et al., 1957). Duodenal and fecal samples were ashed, digested (Williams et al., 1962), and analyzed for chromium using a Varian Spectra AA-30 atomic absorption spectrophotometer (Varian, Walnut Creek, CA). Duodenal samples were prepared for fatty acid analysis according to the boron trifluoride-methanol procedure outlined by Metcalfe et al. (1966). Fatty acid methyl esters were analyzed via GLC on a Hewlett Packard 5890A (Houston, TX) with a flame ionization detector equipped with a 30-m x 0.25-mm i.d. Supelco SP-2330 poly phase column (Agilent; Santa Clara, CA). Hydrogen was used as the carrier gas. The injector, detector, and oven temperatures were set at 270,300 , and $190^{\circ} \mathrm{C}$, respectively.

Microbial OM and CP flow to the duodenum was estimated assuming a 0.3 purine:N ratio outlined by Cooper et al. (2002). Organic matter fermented in the rumen was calculated as OM intake minus total OM reaching the duodenum corrected for microbial OM reaching the duodenum. Microbial OM was assumed to be equal to microbial $\mathrm{N} \div 0.0996$ (Clark et al., 1992). 
Microbial DM was assumed to contain 21\% starch (NRC, 1996), which was necessary for calculating true ruminal starch digestibilities.

Wet distillers grains plus solubles were procured from a commercial ethanol plant (Abengoa Bioenergy, York, NE) on a weekly basis delivered to the University of Nebraska's research feedlot. Roughly 205 L of WDGS was loaded into barrels, shipped to the metabolism area, and stored at $-4^{\circ} \mathrm{C}$ until experimental diets were mixed. Corn bran and corn gluten meal were obtained from a wet-milling facility (Cargill, Blair, NE) all at once, and delivered to the metabolism area in plywood boxes.

All data were analyzed as a 5 x 5 Latin square design using the MIXED procedure of SAS (SAS Inst. Inc., Cary, NC) with steer (random effect) x period (fixed effect) as the experimental unit. Repeated samples were made on experimental units for VFA. These data were also analyzed as a repeated measurement, with hour repeated. Autoregressive (AR-1) covariance structures were utilized with final covariance structure based on the lowest Akaike information criterion for covariance structures with successful convergence. Fixed effects of treatment were deemed significant when $P \leq 0.10$.

\section{RESULTS AND DISCUSSION}

\section{Experiment 1}

No significant differences $(P>0.10)$ were observed for the main effects or interaction for initial BW, final BW, HCW, or DMI (Table 4). However, DMI tended $(P=0.13)$ to decrease linearly as fat provided from WDGS or corn oil in the diet increased. Zinn (1994) indicated that the upper limit for supplemental fat was $4 \%$ of dietary DM; however, further trials conducted by Zinn (1988, 1989a, 1989b) observed no effect of supplemental fat level on DMI. Characteristics 
of the supplemental fat source such as degree of unsaturation and amount of free fatty acids (Zinn, 1989b), or energy density of the basal dietary ingredients and overall diet acceptability may inhibit feed intake (Zinn, 1989a). Unsaturated fatty acids have greater effects on growth of cellulolytic bacteria and protozoal populations compared to SFA (Henderson, 1973). Jenkins (1987) determined that high FFA content of blended fats had less inhibitory effects on ruminal fermentation compared with unblended fat sources. Zinn (1989a) reported that increasing the energy density of diets with fat supplementation should increase energy intake. Contrary to Zinn (1989a), Hale (1986) reported that the performance response to supplemental fat is poorer with corn-based diets than for wheat-, barley-, or milo-based diets, which may be due to corn having a higher fat content than wheat, barley, or milo (NRC, 1996).

Hatch et al. (1972) reported that a marked reduction in feed intake (appeared to be a linear decrease from $0,3,6$, or $9 \%$ added fat) is the most consistent detrimental effect observed with fat supplementation of 6 or $9 \%$, and may continually affect growth rate and impede performance upon totally removing the supplemental fat from the diet. However, these authors were unsure as to whether a drop in intake is due to diet acceptability or metabolic regulation. Zinn (1994) observed a linear decrease in observed:expected dietary NE for daily lipid intakes greater than $1.6 \mathrm{~g} / \mathrm{kg} \mathrm{BW}$. This lipid intake would equate to a maximum dietary lipid content of $8 \%$ of the diet DM for a $500-\mathrm{kg}$ animal with a daily intake at $2.0 \%$ of BW.

In the present study, the 2.5FAT and 20DG diets, as well as the 5FAT and 40DG diets were formulated to be equal in EE. The EE analysis averaged 6.37 and $8.76 \%$ (DM basis) for the medium and high levels of fat, respectively. Dry matter intakes for the 2.5FAT, 5FAT, 20DG, and 40DG diets were 9.1, 8.2, 9.1, and $8.9 \mathrm{~kg} / \mathrm{d}$, respectively, therefore using the average initial and final BW for each dietary treatment would equate to lipid consumptions of $1.34,1.74$, 
1.35, and $1.83 \mathrm{~g} / \mathrm{kg}$ of BW for the 2.5FAT, 5FAT, 20DG, and 40DG diets, respectively. Dietary lipid intake values for both the 5FAT and 40DG diets surpassed the $1.6 \mathrm{~g} / \mathrm{kg}$ of BW suggested by Zinn (1994) as being optimum for performance.

A source $\mathrm{x}$ level interaction $(P<0.10)$ was observed for both ADG and G:F. As supplemental corn oil increased, ADG decreased linearly $(P=0.04)$. As WDGS increased, no effect $(P>0.50)$ was observed for ADG. Heifers on the 5FAT treatment had lower ADG than heifers on any other treatment $(1.13 \mathrm{~kg} / \mathrm{d}$ vs. $1.4 \mathrm{~kg} / \mathrm{d})$. Similarly, the simple effects of level within source indicated that G:F decreased linearly as corn oil in the diet increased $(P=0.10)$. Similar to ADG, no effect $(\mathrm{P}>0.20)$ was observed for G:F. In terms of dietary $\mathrm{NE}_{\mathrm{g}}$ concentrations, there was a tendency $(P=0.16)$ for the source by level interaction to be significant, with dietary $\mathrm{NE}_{\mathrm{g}}$ concentrations decreasing linearly as the amount of corn oil in the diet increased.

Gain efficiency in the present study indicated that the fat in WDGS contributes to the higher energy value relative to corn; however, the magnitude of the fat contribution alone is not certain. Al-Suwaiegh et al. (2002) attributed $42 \%$ of the overall improvement in $\mathrm{NE}_{\mathrm{g}}$ content of the diets to the fat content of distillers grains. The authors suggested that the remaining $58 \%$ may be attributed to the additions of yeast and yeast byproducts, excess protein used for energy, added moisture, cofactors, differences in the non-fiber carbohydrate fraction, or a reduction in subacute acidosis. Trenkle (1996) suggested that the greater concentration of fat in WDGS contributes more energy than corn grain, but cannot account for the entire difference. He also stated that the higher energy value may be due to the concept that feeding WDGS with corn may result in greater utilization of the starch in corn. Grant (1997) mentioned the ability of high forage diets to increase the digestibility of starch in corn, which was directly related to particle 
size and a slower passage rate. However, he also noted that this might not hold true for nonforage fiber sources, due to particle size being smaller, thus increasing passage rate.

In the present study, WDGS was included in the diet by replacing a blend of HMC and DRC, a rapidly fermentable carbohydrate combination (Britton and Stock, 1987, Stock et al., 1990). Upon consumption of rapidly fermentable carbohydrates, organic acids are produced in the rumen (Britton and Stock, 1987) which results in an almost immediate drop in ruminal $\mathrm{pH}$. The primary symptom of subacute acidosis in finishing cattle is reduced feed intake (Fulton et al., 1979). In a metabolism trial conducted by Zinn (1989b), supplemental fat had no effect on ruminal $\mathrm{pH}$. Therefore, in the present trial it appears that subacute acidosis was not responsible for impeding intake of heifers on the 5FAT diet any more than it would have for heifers on the OFAT, ODG, or 2.5FAT diets.

Calculated from animal performance (Owens et al., 2002), the 20DG and 40DG diets provided $2.5 \%$ and $6.8 \%$ more $\mathrm{NE}_{\mathrm{g}}$ than the $\mathrm{ODG}$ diet. These results follow a similar pattern as those of Larson et al. (1993) who observed 5.8, 10.7, and 22\% improvements in diet $\mathrm{NE}_{\mathrm{g}}$ when WDGS was fed to yearlings at 5.2, 12.6, and $40 \%$ of the diet DM. Results reported by Ham et al. (1994) with a WDGS inclusion of $40 \%$ (DM basis) indicate a $17 \%$ greater diet $\mathrm{NE}_{\mathrm{g}}$ relative to a dry-rolled corn control. Larson et al. (1993) and Ham et al. (1994) concluded that the greater diet $\mathrm{NE}_{\mathrm{g}}$ was attributable to increased energy utilization. The increase in $\mathrm{NE}_{\mathrm{g}}$ from WDGS was less in this study compared to observations by Larson et al. (1993) and Ham et al. (1994). One potential difference between these studies is corn processing method because WDGS was compared to DRC by Larson et al. (1993) and Ham et al. (1994), whereas the WDGS in the present study was compared to a combination of HMC and DRC. High-moisture and dry-rolled corn fed in combination has been shown to provide more $\mathrm{NE}_{\mathrm{g}}$ than feeding either corn type 
separately (Stock et al., 1987). Stock et al. (2000), in a review of wet and dry milling byproducts, emphasized that greater feed efficiencies cannot be explained by increased digestibility, but a combination of factors including reduced acidosis, improved energy utilization, and yeast end-products.

No significant differences were observed for the main effects or interaction on $12^{\text {th }}$ rib fat thickness, LM area, or USDA Yield Grade. A significant difference was observed for the main effect of source on marbling score. Heifers on the corn oil treatments had lower $(P<0.10)$ marbling scores than heifers on the WDGS treatments.

\section{Experiment 2}

No significant $(P>0.10)$ differences were observed for any performance parameter or carcass characteristic measurement (Table 5). Steers fed either the 2.6TAL or 40DG diets had the greatest numerical ADG and G:F, but these differences were not significant $(P>0.20)$. Net energy for gain, calculated utilizing performance inputs (Owens et al., 2002), indicated that DDGS when fed at $20 \%$ of DM was $97.3 \%$ of HMC, and when fed at $40 \%$ of DM was $103 \%$ of HMC.

In the present study, within level of supplemental fat, diets appear to contain similar amounts of total lipid (Table 2). Dry distillers grains plus solubles were sampled periodically and averaged $8.1 \%$ total lipid (DM basis), whereas the WDGS mixture utilized in Exp. 1 averaged $16.5 \%$ total lipid (DM basis). Therefore, corn oil supplementation was greater in Exp. 1 due to the higher lipid content of the WDGS. In Exp. 2, tallow supplementation was less due to the lower lipid content of DDGS. In the present study, cattle did not surpass the total lipid intake threshold of 7.5 to $8.0 \%$ discussed previously. The energy value of WDGS in Exp. 1 was greater than the energy value of DDGS in Exp. 2. This may be explained by WDGS having a 
greater energy value than DDGS in finishing diets as reported by Ham et al. (1994). Klopfenstein et al. (2008) concluded that WDGS contains more energy than DDGS when fed to finishing steers based on a summary of feeding experiments using the 2 types of distillers grains. Another difference between Exp. 1 and Exp. 2 was the grain source, with Exp. 2 containing only HMC, whereas a 50:50 blend of HMC and DRC were fed in Exp. 1. Lastly, an important difference between experiments was that diets fed in Exp. 1 did not contain WCGF, whereas all diets contained 20\% WCGF in Exp. 2 to aid in acidosis control. Surprisingly, no response to added fat was observed whether from DDGS or tallow in this experiment which contradicts previous research by Richards et al. (1998).

Distinct differences existed between fat sources (corn oil and tallow) utilized in Exp. 1 and Exp. 2. Corn oil consists primarily of unsaturated fatty acids, whereas tallow is comprised of both saturated and unsaturated fatty acids (USDA, 2005). Work conducted by Zinn (1989a) evaluating multiple fat sources, indicated that the comparative feeding value, in terms of diet acceptability and NE value is not influenced by fat source. However, additional work by Zinn (1989b) indicated that fat sources comprised primarily of SFA improved ruminal fiber digestion and resulted in greater molar proportions of propionate relative to fat sources comprised primarily of unsaturated fat sources. Therefore, fiber digestion in cattle receiving corn oil in Exp. 1 may not have been as great as fiber digestion in cattle receiving tallow in Exp. 2 . However, the effect of corn oil on fiber digestion for cattle receiving WDGS would be expected to be similar to cattle receiving only corn oil unless the oil is "protected" from microbes. This protection may occur if the oil is still in the intact germ portion of the kernel and, therefore, not inhibitory to microbes. However, Montgomery et al. (2005) did not observe a difference between cattle fed full-fat germ from corn or tallow with diets containing $4 \%$ supplemental fat. 
Replacing corn with a highly digestible fiber source such as DDGS/WDGS (Farlin, 1981; Firkins et al., 1985) may decrease the possibility of cattle experiencing subacute acidosis (Larson et al., 1993; Rust et al., 1990; Firkins et al., 1985). Krehbiel et al. (1995) determined that cattle consuming WCGF in finishing diets were less susceptible to subacute acidosis than cattle not fed WCGF. Additionally, Krehbiel et al. (1995) determined the incidence/severity of subacute acidosis by measuring ruminal $\mathrm{pH}$ over time, as well as by analyzing intake variation. In Exp. 2, WCGF was included in all diets at $20 \%$ of DM, which should have minimized the potential for a subacute acidosis challenge. Therefore, results indicate that providing similar quantities of supplemental fat through tallow supplementation was similar to feeding DDGS.

\section{Experiment 3}

Average ruminal $\mathrm{pH}$ was greatest $(P<0.10)$ for the COMP + OIL treatment and numerically lowest for the WDGS treatment, but maximum $\mathrm{pH}$, minimum $\mathrm{pH}$, and $\mathrm{pH}$ change were not different among treatments (Table 6). Time below pH 5.6 was the least $(P<0.10)$ for the COMP + OIL treatment and numerically greatest for WDGS. No differences were observed between treatments for time below $\mathrm{pH} 5.3$ or 5.0. These results are contrary to $\mathrm{pH}$ values observed by Krehbiel et al. (1995) who fed diets containing WCGF or DRC. However, relative to the diets containing corn bran, these data are in agreement with observations by Sayer (2004) who observed higher ruminal $\mathrm{pH}$ values for diets that contain 30 or $45 \%$ (DM basis) corn bran relative to a DRC based high concentrate diet.

Molar proportions of acetate were lower $(P<0.10)$ and propionate were higher $(P<$ 0.10) for the WDGS treatment. Molar proportion of butyrate was not affected by treatment. Lower acetate and greater propionate molar proportions for the WDGS treatment led to the acetate:propionate ratio being lower $(P<0.10)$ for the WDGS compared with the other 
treatments. The greater acetate:propionate ratios for the diets containing corn bran indicate fiber digestion was being promoted. Sayer (2004) observed an increase in acetate:propionate ratio as corn bran inclusion increased from 0 to $45 \%$ of DM. Further, Grant (1997) suggested that replacing concentrates with high quality fiber sources increased acetate:propionate ratio and subsequent milk fat percentage in lactation diets. However, Scott et al. (1998) reported a decrease in acetate:propionate ratio as inclusion of corn steep, a liquid byproduct from wet milling plants, increased. The components of WDGS are distillers grains and condensed distillers solubles. With the exception of fat content, condensed distillers solubles can have similar nutritive properties to steep depending on the level of distillers solubles present in steep. The potential similarities of condensed distillers solubles and steep may explain the lower acetate:propionate ratio observed for the WDGS treatment in the present study. Ham et al. (1994) observed greater acetate:propionate ratios in diets containing wet distillers grains than diets containing DRC, and a lower acetate:propionate ratio than DRC for diets containing thin stillage. With the exception of DM, thin stillage should be similar in nutrient composition to distillers solubles.

Dry matter and OM intakes were lowest $(P<0.10)$ for cattle fed the CON + OIL diet (Table 7). Intake of NDF was greatest $(P<0.10)$ for cattle fed the COMP and COMP + OIL diets and least $(P<0.10)$ for cattle fed the CON and CON + OIL diets. Starch intake was greatest $(P<0.10)$ for cattle fed the CON diet. Dietary fat intake was greatest $(P<0.10)$ for cattle fed the WDGS and CON + OIL diets and least $(P<0.10)$ for cattle fed the COMP and CON diets. The primary factor responsible for the lower starch and fat intake for cattle fed the $\mathrm{CON}+\mathrm{OIL}$ diet is the low overall DMI compared with cattle fed the other diets. These data agree with Belknap and Trenkle (2000) who supplemented corn oil to DRC based diets to 
achieve fat concentrations similar to those provided by a diet comprised predominantly of highoil corn. It appears that the lower DMI for cattle fed the CON + OIL diet may be related to the amount of corn oil added to the diet (Zinn, 1994). However, corn oil did not affect the DMI of cattle fed the COMP + OIL diet; therefore, the interaction between corn oil and the additional DRC relative to the COMP + OIL treatment is likely responsible for the reduction in DMI for the $\mathrm{CON}+$ OIL treatment.

Ruminal apparent OM, true OM, and NDF digestibility were not different among treatments (Table 7). Ruminal apparent starch and true starch digestibility were less $(P<0.10)$ for cattle fed the CON + OIL diet than for cattle fed the other diets. The values reported in the present study for true ruminal starch digestibility for cattle receiving the CON and CON + OIL diets are in close agreement with values reported by Cooper et al. (2002) and Huntington (1997) who evaluated DRC-based diets.

Total tract DM, OM, and NDF digestibilities were less $(P<0.10)$ for cattle fed the COMP and COMP + OIL diets compared with cattle fed the WDGS, CON, and CON + OIL diets. Total-tract OM digestibility for cattle fed the WDGS diet in the present study were similar (82.5 vs. $81.3 \%$ ) to those reported by Ham et al. (1994); however, total-tract NDF digestibility was greater in the present study than that reported by Ham et al. (1994). Similarly, total-tract OM digestibility for cattle fed the COMP and COMP + OIL diets in the present study were in close agreement with values published by Sayer (2004). Additionally, total-tract OM digestibility of cattle fed the CON and CON + OIL diets were in close agreement with values published by Cooper et al. (2002).

Total-tract starch digestibility was greater $(P<0.10)$ for cattle fed the WDGS diet, relative to cattle fed the COMP + OIL and CON + OIL diets. Therefore, it appears that 
supplemental corn oil may impede total tract starch digestion relative to similar fat supplied by WDGS. Zinn (1989b) observed no difference in total tract starch digestion when fat was supplemented at 4 and $8 \%$ of DM relative to a control with no supplemental fat. However, Zinn (1989b) did observe a significant decrease in total tract OM digestion when supplemental fat increased from 0 to $8 \%$ of the diet (DM basis). Additionally, Ham et al. (1994) observed an improvement in total tract starch digestion for diets containing wet distillers grains which was greater than that for DRC; diets containing thin stillage were greater than both wet distillers grains and DRC. Therefore, the WDGS appears to have a positive effect on total-tract starch digestion with the fat content of WDGS not negatively affecting starch digestion, whereas corn oil supplementation can negatively affect starch digestion.

Total tract fat digestibility was greatest $(P<0.10)$ for cattle fed the WDGS diet and lowest $(P<0.10)$ for cattle fed the COMP diet. Zinn et al. (2000) reported that expected intestinal digestibility of fat is $77 \%$ at typical levels of fat intake $(1.2 \mathrm{~g} / \mathrm{kg} \mathrm{BW}$ daily $)$. Values observed for fat digestibility for the WDGS were greater and values reported for the other dietary treatments were less than the expected value reported by Zinn et al. (2000). Plascencia et al. (2003) explained that the low intestinal digestibility of fat is due to extensive ruminal biohydrogenation of fatty acids. Additionally, Atkinson et al. (2006) indicated that feeding highconcentrate diets can result in decreased ruminal biohydrogenation, which can lead to greater unsaturated fatty acid concentrations in tissues. This, coupled with lower fat intakes may explain why cattle fed the CON and CON + OIL diets had greater total fat digestibility than cattle fed the COMP and COMP + OIL diets.

Cattle receiving the WDGS and CON diets had greater $(P<0.10)$ proportions of 16:0 reaching the duodenum than cattle receiving the COMP, COMP + OIL, and CON + OIL diets 
(Table 8). In terms of the long chain fatty acids, cattle receiving diets supplemented with corn oil had greater $(P<0.10)$ proportions of 18:0 reaching the duodenum, whereas cattle receiving the WDGS diet had the least $(P<0.10)$ amount of 18:0 reaching the duodenum. Contrary to this, cattle receiving WDGS had greater proportions of 18:1 trans, 18:1, and 18:2 reaching the duodenum relative to cattle fed the other diets, whereas cattle receiving diets supplemented with corn oil had the least amount of 18:1 trans, 18:1, and 18:2 reaching the duodenum. These data indicate that the fatty acids in WDGS are not hydrogenated to the same extent in the rumen as fatty acids in supplemental corn oil. Zinn et al. (2000) indicated that the intestinal absorption of fatty acids is contingent upon the formation of bile salt micelles, and that the greater the surface area of micelles, the greater digestibility of fat. Further, these authors explained that the surface area of the micelles is enhanced by the interaction of bile salts and insoluble swelling amphophiles which are characteristic of unsaturated fatty acids. Therefore, according to Zinn et al. (2000), it appears that unsaturated fatty acids have greater intestinal digestibility than SFA. Lock et al. (2005) suggested that digestibility of individual fatty acids decreases as chain length increases, and increases as the number of double bonds increases. Additionally, these authors mentioned that the mean intestinal digestibility for 16:0, 18:0, 18:1, 18:2, and 18:3 are 75, 72, 80,78 , and $77 \%$, respectively. Therefore, it appears that the fat in WDGS is more digestible than supplemental corn oil due to the fact it supplies greater amounts of unsaturated fatty acids to the duodenum relative to supplemental corn oil.

We can conclude that equal amounts of fat provided from wet distillers grains plus solubles or corn oil do not result in similar animal performance. High-moisture corn based finishing diets containing $20 \%$ wet corn gluten feed and equal amounts of fat from dry distillers grains plus solubles or tallow result in similar finishing performance of yearling steers. The 
higher energy value of wet distillers grains plus solubles relative to corn appears to be related to a lower acetate:propionate ratio, greater fat digestibility, and more unsaturated fatty acids reaching the duodenum or a combination of all these. 


\section{LITERATURE CITED}

Al-Suwaiegh, S., K. C. Fanning, R. J. Grant, C. T. Milton, and T. J. Klopfenstein. 2002. Utilization of distillers grains from the fermentation of sorghum and corn in diets for finishing beef and lactating dairy cattle. J. Anim. Sci. 80:1105-1111.

AOAC. 1965. Official Methods of Analysis (10 ${ }^{\text {th }}$ Ed.). Association of Official Analytical Chemists, Washington, DC.

AOAC. 1999. Official Methods of Analysis of AOAC International. $16^{\text {th }}$ Ed., $5^{\text {th }}$ revision, 1999. Edited by Patricia Cunniff. AOAC international, Gaithersburg, MD.

Atkinson, R. L., E. J. Scholljegerdes, S. L. Lake, V. Nayigihugu, B. W. Hess, and D. C. Rule. 2006. Site and extent of digestion, duodenal flow, and intestinal disappearance of total and esterified fatty acids in sheep fed a high-concentrate diet supplemented with highlinoleate safflower oil. J. Anim. Sci. 84:387-396.

Belknap, C. R., and A. Trenkle. 2000. The effects of high-oil corn or typical corn with or without supplemental fat on diet digestibility in finishing steers. Iowa State Univ. Beef Cattle Res. Rep. A.S. Leaflet R1719.

Britton, R. A., and R. A. Stock. 1987. Acidosis, rate of starch digestion and intake. In: F.N. Owens (ed.). Symp. Proc.: Feed intake by beef cattle. Publ. MP 121 p. 125. Oklahoma State Univ., Stillwater.

Clark, J. H., T. H. Klusmeyer, and M. R. Cameron. 1992. Microbial protein synthesis and flows of nitrogen fractions to the duodenum of dairy cows. J. Dairy Sci. 75:2304-2323.

Cooper, R. J., T. J. Klopfenstein, R. A. Stock, C. T. Milton, D. W. Herold, and J. C. Parrott. 1999. Effects of imposed feed intake variation on acidosis and performance of finishing steers. J. Anim. Sci. 77:1093-1099. 
Cooper, R. J., C. T. Milton, T. J. Klopfenstein, T. L. Scott, C. B. Wilson, and R. A. Mass. 2002. Effect of corn processing on starch digestion and bacterial crude protein flow in finishing cattle. J. Anim. Sci. 80:797-804.

Erwin, E. S., D. J. Marco, and E. M. Emery. 1961. Volatile fatty acid analysis of blood and rumen fluid by gas chromatography. J. Dairy Sci. 44:1768-1770.

Farlin, S. D. 1981. Wet distillers grain for finishing cattle. Anim. Nutr. Health. 36:35-36.

Firkins, J. L., L. L. Berger, and G. C. Fahey. 1985. Evaluation of wet and dry distillers grains and wet and dry corn gluten feeds for ruminants. J. Anim. Sci. 60:847-860.

Folch, J., M. Lees, and G. H. Sloane-Stanley. 1957. A simple method for the isolation and purification of total lipids from animal tissues. J. Biol. Chem. 224:497-509.

Fulton, W. R., T. J. Klopfenstein, and R. A. Britton. 1979. Adaptation to high concentrate diets by beef cattle. II. Effect of ruminal $\mathrm{pH}$ alteration on rumen fermentation and voluntary intake of wheat diets. J. Anim. Sci. 49:785-789.

Grant, R. J. 1997. Interactions among forages and nonforage fiber sources. J. Dairy Sci. 80:1438-1446.

Hale, W. H. 1986. Fat in diets for growing finishing cattle. In: Proc. Southwest Nutr. Conf., Tempe, AZ. p 46.

Ham, G. A., R. A. Stock, T. J. Klopfenstein, E. M. Larson, D. H. Shain, and R. P. Huffman. 1994. Wet corn distillers byproducts compared with dried corn distillers grains with solubles as a source of protein and energy for ruminants. J. Anim. Sci. 72:3246-3257.

Hatch, C. F., T. W. Perry, M. T. Mohler, and W. M. Beeson. 1972. Effect of added fat with graded levels of calcium to urea-containing rations for beef cattle. J. Anim. Sci. 34:483491. 
Henderson, C. 1973. The effects of fatty acids on pure cultures of rumen bacteria. J. Agric. Sci. (Camb.) 81:107-112.

Huntington, G. B. 1997. Starch utilization by ruminants: From basics to the bunk. J. Anim. Sci. 75:852-867.

Jenkins, T. C. 1987. Effects of fats and fatty acid combinations on ruminal fermentation in semi-continuous in vitro cultures. J. Anim. Sci. 64:1526-1533.

Klopfenstein, T. J., G. E. Erickson, and V. R. Bremer. 2008. BOARD INVITED REVIEW: Use of distillers by-products in the beef cattle feeding industry. J. Anim. Sci. 86:1223-1231.

Krehbiel, C. R., R. A. Stock, D. W. Herold, D. H. Shain, G. A. Ham, and J. E. Carulla. 1995. Feeding wet corn gluten feed to reduce subacute acidosis in cattle. J. Anim. Sci. 73:29312939.

Larson, E. M., R. A. Stock, T. J. Klopfenstein, M. H. Sindt, and R. P. Huffman. 1993. Feeding value of wet distillers byproducts for finishing ruminants. J. Anim. Sci. 71:2228-2236.

Lock, A. L., K. J. Harvatine, I. I. Ipharraguerre, M. Van Amburgh, J. K. Drackley, and D. E. Bauman. 2005. The dynamics of fat digestion in lactating dairy cows: what does the literature tell us? Proc. Cornell Nutr. Conf. pp. 83-94.

Lodge, S. L., R. A. Stock, T. J. Klopfenstein, D. H. Shain, and D. W. Herold. 1997a. Evaluation of corn and sorghum distillers byproducts. J. Anim. Sci. 75:37-43.

Lodge, S. L., R. A. Stock, T. J. Klopfenstein, D. H. Shain, and D. W. Herold. 1997b. Evaluation of wet distillers composite for finishing ruminants. J. Anim. Sci. 75:44-50.

Metcalfe, L. D., A. A. Schmitz, and J. R. Pelka. 1966. Rapid preparation of fatty acid esters from lipids for gas chromatographic analysis. Anal. Chem. 38:514-515. 
Montgomery, S. P., J. S. Drouillard, J. J. Sindt, M. A. Greenquist, B. E. Depenbusch, E. J. Good, E. R. Loe, M. J. Sulpizio, T. J. Kessen, and R. T. Ethington. 2005. Effects of dried full-fat germ and vitamin $\mathrm{E}$ on growth performance and carcass characteristics of finishing cattle. J. Anim. Sci. 83:2440-2447.

NRC. 1996. Nutrient Requirements of Beef Cattle. Update 2000. National Academy Press, Washington, DC.

Owens, F. N., M. A. Hinds, and D. W. Rice. 2002. Methods for calculating diet energy values from feedlot performance of cattle. J. Anim. Sci. 80(Suppl.1):273 (Abstr.).

Plascencia, A., G. D. Mendoza, C. Vásquez, and R. A. Zinn. 2003. Relationship between body weight and level of fat supplementation on fatty acid digestion in feedlot cattle. J. Anim. Sci. 81:2653-2659.

Raun, N. S. and W. Burroughs. 1962. Suction strainer technique in obtaining rumen fluid samples from intact lambs. J. Anim. Sci. 21:454-457.

Richards, C. J., R. A. Stock, T. J. Klopfenstein, and D. H. Shain. 1998. Effect of wet corn gluten feed, supplemental protein, and tallow on steer finishing performance. J. Anim. Sci. $76: 421-428$.

Russell, J. B. 2002. Rumen Microbiology and Its Role in Ruminant Nutrition. @ 2002 by James B. Russell, Ithaca, NY.

Rust, S. R., J. R. Newbold, and K. W. Metz. 1990. Evaluation of condensed distillers solubles as an energy source for finishing cattle. J. Anim. Sci. 68:186-192.

Sayer, K. M. 2004. Effects of corn bran and steep inclusion in finishing diets on cattle performance, nutrient mass balance, and diet digestibility. M.S. Thesis. Univ. of Nebraska, Lincoln. 
Scott, T., T. Klopfenstein, R. Stock, and R. Cooper. 1998. Metabolism and digestibility of corn bran and corn steep liquor/distillers solubles. Neb. Beef Cattle Rep. MP 69-A:69-71.

Stock, R. A., D. R. Brink, R. T. Brandt, J. K. Merrill, and K. K. Smith. 1987. Feeding combinations of high moisture corn and dry corn to finishing cattle. J. Anim. Sci. 65:282-289.

Stock, R. A., J. M. Lewis, T. J. Klopfenstein, and C. T. Milton. 2000. Review of new information on the use of wet and dry milling feed by-products in feedlot diets. J. Anim. Sci. Available: http://www.asas.org/symposia/proceedings/0924.pdf. Accessed: Jan. 14, 2006.

Stock, R. A., M. H. Sindt, J. C. Parrott, and F. K. Goedeken. 1990. Effects of grain type, roughage level and monensin level on finishing cattle performance. J. Anim. Sci. $68: 3441-3455$.

Trenkle, A. 1996. Evaluation of wet distillers grains for finishing cattle. Iowa State Univ. Beef Cattle Res.Rep. A.S. Leaflet R1342.

USDA. 2005. USDA National Nutrient Database for Standard Reference, Release 18. Nutrient Data Laboratory Home Page, http://www.ars.usda.gov/ba/bhnrc/ndl Accessed: March 16, 2006.

Vander Pol, K. J., G. E. Erickson, T. J. Klopfenstein, M. A. Greenquist, and T. Robb. 2006. Effect of dietary inclusion of wet distillers grains on feedlot performance of finishing cattle and energy value relative to corn. Nebraska Beef Cattle Rep. MP 88-A:51-53.

Van Soest, P. J., J. B. Robertson, and B. A. Lewis. 1991. Methods for dietary fiber, neutral detergent fiber, and nonstarch polysaccharides in relation to animal nutrition. J. Anim. Sci. 24:834-843. 
Williams, C. H., D. J. David, and O. Iismaa. 1962. The determination of chromic oxide in feces samples by atomic absorption spectrophotometry. J. Agric. Sci. (Camb.) 59:381-385.

Zinn, R. A. 1988. Comparative feeding value of supplemental fat in finishing diets for feedlot steers supplemented with and without monensin. J. Anim. Sci. 66:213-227.

Zinn, R. A. 1989a. Influence of level and source of dietary fat on its comparative feeding value in finishing diets for steers: feedlot cattle growth and performance. J. Anim. Sci. 67:1029-1037.

Zinn, R. A. 1989b. Influence of level and source of dietary fat on its comparative feeding value in finishing diets for feedlot steers: metabolism. J. Anim. Sci. 67:1038-1049.

Zinn, R. A. 1994. Effects of excessive supplemental fat on feedlot cattle growth performance and digestive function. Prof. Anim. Sci. 10:66-72.

Zinn, R. A., S. K. Gulati, A. Plascencia, and J. Salinas. 2000. Influence of ruminal biohydrogenation on the feeding value of fat in finishing diets for feedlot cattle. J. Anim. Sci. 78:1738-1746. 
Table 1. Composition of diets (\% of diet DM) fed to individually fed heifers (Exp. 1)

\begin{tabular}{|c|c|c|c|c|c|c|}
\hline & \multicolumn{6}{|c|}{ Treatment ${ }^{1}$} \\
\hline Item & OFAT & 2.5FAT & 5FAT & ODG & 20DG & 40DG \\
\hline Dry-rolled corn & 43.75 & 42.5 & 41.25 & 43.75 & 33.75 & 23.75 \\
\hline High-moisture corn & 43.75 & 42.5 & 41.25 & 43.75 & 33.75 & 23.75 \\
\hline Distillers grains & --- & --- & --- & --- & 13.0 & 26.0 \\
\hline Distillers solubles & --- & --- & --- & --- & 7.0 & 14.0 \\
\hline Alfalfa hay & 7.5 & 7.5 & 7.5 & 7.5 & 7.5 & 7.5 \\
\hline Corn oil & --- & 2.5 & 5.0 & --- & --- & --- \\
\hline Dry supplement $^{2}$ & 5.0 & 5.0 & 5.0 & 5.0 & 5.0 & 5.0 \\
\hline Fine ground corn & 1.56 & 1.43 & 1.30 & 1.56 & 2.45 & 3.27 \\
\hline Urea & 1.15 & 1.23 & 1.31 & 1.15 & 0.57 & --- \\
\hline Limestone & 1.09 & 1.05 & 1.00 & 1.09 & 1.13 & 1.18 \\
\hline Potassium chloride & 0.39 & 0.40 & 0.42 & 0.39 & 0.19 & --- \\
\hline Salt & 0.30 & 0.30 & 0.30 & 0.30 & 0.30 & 0.30 \\
\hline Calcium sulfate & 0.22 & 0.23 & 0.25 & 0.22 & 0.11 & --- \\
\hline Tallow & 0.15 & 0.15 & 0.15 & 0.15 & 0.15 & 0.15 \\
\hline Beef trace mineral $^{3}$ & 0.05 & 0.05 & 0.05 & 0.05 & 0.05 & 0.05 \\
\hline Dicalcium phosphate & 0.04 & 0.11 & 0.17 & 0.04 & --- & --- \\
\hline Rumensin- $80^{4}$ & 0.02 & 0.02 & 0.02 & 0.02 & 0.02 & 0.02 \\
\hline Tylan- $40^{5}$ & 0.01 & 0.01 & 0.01 & 0.01 & 0.01 & 0.01 \\
\hline MGA $^{6}$ & 0.01 & 0.01 & 0.01 & 0.01 & 0.01 & 0.01 \\
\hline Vitamin A-D-E $^{7}$ & 0.01 & 0.01 & 0.01 & 0.01 & 0.01 & 0.01 \\
\hline \multicolumn{7}{|l|}{ Nutrient composition $^{8}$} \\
\hline $\mathrm{CP}$ & 12.5 & 12.5 & 12.5 & 12.5 & 13.6 & 17.8 \\
\hline DIP, $\%$ of CP & 7.53 & 7.61 & 7.69 & 7.53 & 6.53 & 6.70 \\
\hline Calcium & 0.60 & 0.60 & 0.60 & 0.60 & 0.60 & 0.60 \\
\hline Phosphorus & 0.30 & 0.30 & 0.30 & 0.30 & 0.37 & 0.45 \\
\hline Potassium & 0.60 & 0.60 & 0.60 & 0.60 & 0.60 & 0.60 \\
\hline Ether extract & 3.98 & 6.37 & 8.76 & 3.98 & 6.39 & 8.80 \\
\hline
\end{tabular}

${ }^{1}$ OFAT $=0 \%$ corn oil diet, $2.5 \mathrm{FAT}=2.5 \%$ corn oil diet, $5 \mathrm{FAT}=5.0 \%$ corn oil diet, $0 \mathrm{DG}=0 \%$ wet distillers grains plus solubles (WDGS) diet, 20DG $=20 \%$ WDGS diet, 40DG $=40 \%$ WDGS diet.

${ }^{2}$ Supplement formulated to be fed at $5 \%$ of diet DM.

${ }^{3}$ Premix contained $10 \% \mathrm{Mg}, 6 \% \mathrm{Zn}, 4.5 \% \mathrm{Fe}, 2 \% \mathrm{Mn}, 0.5 \% \mathrm{Cu}, 0.3 \% \mathrm{I}, 0.05 \% \mathrm{Co}$.

${ }^{4}$ Premix contained $176 \mathrm{~g}$ monensin $/ \mathrm{kg}$.

${ }_{6}^{5}$ Premix contained 88 g tylosin $/ \mathrm{kg}$.

${ }^{6}$ Premix contained $441 \mathrm{mg}$ melengestrol acetate $/ \mathrm{kg}$.

${ }^{7}$ Premix contained 1,500 IU vitamin A, 3,000 IU vitamin D, 3.7 IU vitamin E per g.

${ }^{8}$ Nutrient analysis measured for CP. Ether extract was calculated from individual ingredient analysis and its corresponding dietary inclusion. Degradable intake protein (DIP), Ca, P, and K were based on formulation. 
Table 2. Composition of diets (\% of diet DM) fed to finishing steers (Exp. 2)

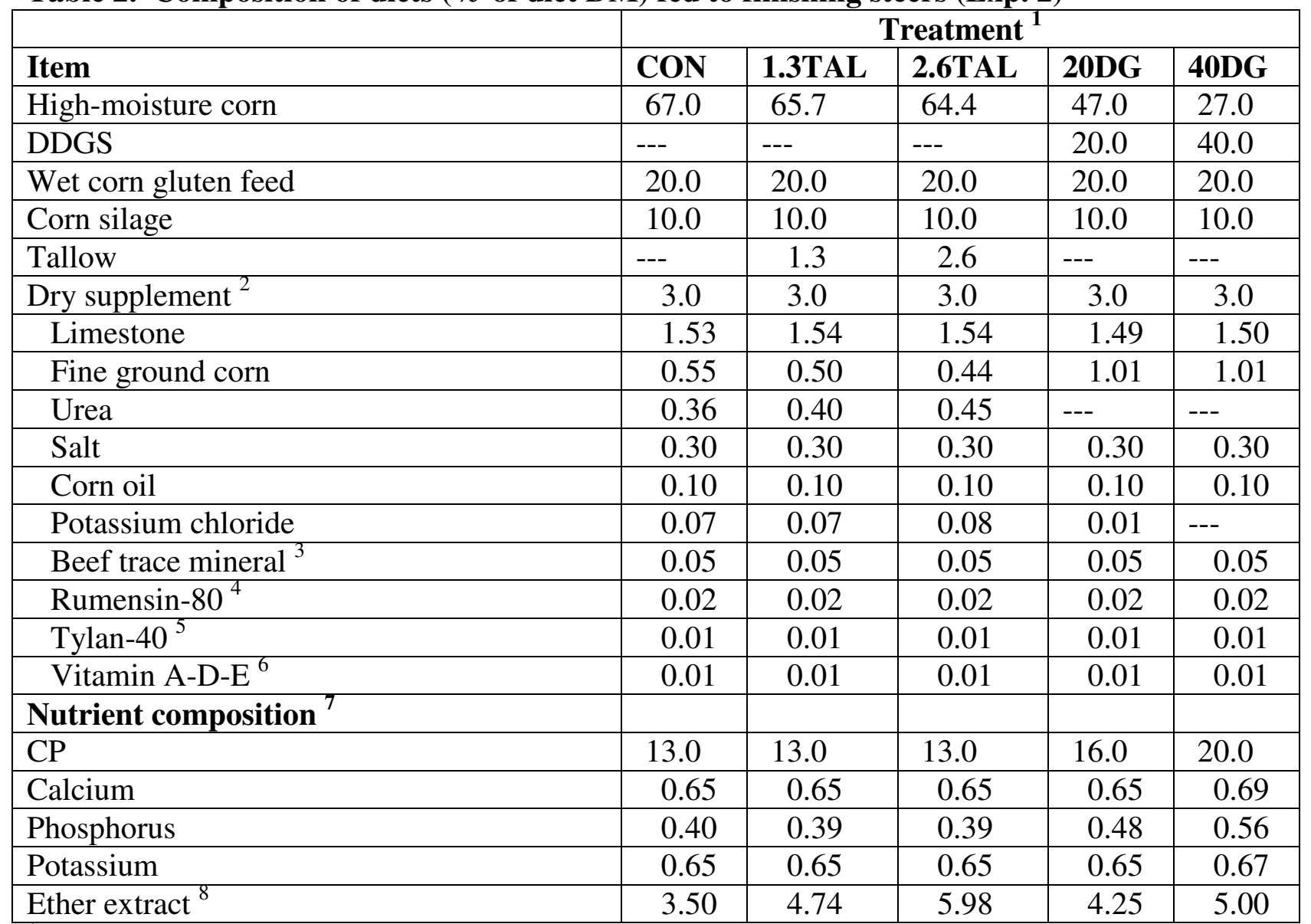

${ }^{1} \mathrm{CON}=$ control diet, $1.3 \mathrm{TAL}=1.3 \%$ tallow, $2.6 \mathrm{TAL}=2.6 \%$ tallow diet, $20 \mathrm{DG}=20 \%$ dry distillers grains plus solubles (DDGS) diet, $40 \mathrm{DG}=40 \%$ DDGS diet.

${ }^{2}$ Supplement formulated to be fed at $3 \%$ of diet DM.

${ }^{3}$ Premix contained $10 \% \mathrm{Mg}, 6 \% \mathrm{Zn}, 4.5 \% \mathrm{Fe}, 2 \% \mathrm{Mn}, 0.5 \% \mathrm{Cu}, 0.3 \% \mathrm{I}, 0.05 \% \mathrm{Co}$.

${ }^{4}$ Premix contained $176 \mathrm{~g}$ monensin/kg.

${ }^{5}$ Premix contained $88 \mathrm{~g}$ tylosin $/ \mathrm{kg}$.

${ }^{6}$ Premix contained 1,500 IU vitamin A, 3,000 IU vitamin D, 3.7 IU vitamin E per g.

${ }^{7}$ Nutrient analyses calculated from tabular values for individual ingredients and its corresponding dietary inclusion.

${ }^{8}$ Ether extract was measured on individual ingredient analysis and calculated for diets based on dietary inclusion. 
Table 3. Composition of diets (\% of diet DM) fed to Holstein steers (Exp. 3)

\begin{tabular}{|c|c|c|c|c|c|}
\hline . & \multicolumn{5}{|c|}{ Treatment ${ }^{1}$} \\
\hline Item & WDGS & COMP & COMP + OIL & CON & $\mathrm{CON}+\mathrm{OIL}$ \\
\hline Dry-rolled corn & 51.0 & 46.8 & 42.7 & 88.0 & 84.6 \\
\hline WDGS & 40.0 & --- & --- & --- & --- \\
\hline Corn bran & --- & 29.6 & 29.6 & --- & --- \\
\hline Corn gluten meal & --- & 11.6 & 11.6 & --- & --- \\
\hline Alfalfa hay & 5.0 & 5.0 & 5.0 & 5.0 & 5.0 \\
\hline Corn oil & --- & --- & 4.1 & --- & 3.4 \\
\hline Molasses & --- & 3.0 & 3.0 & 3.0 & 3.0 \\
\hline Dry supplement ${ }^{2}$ & 4.0 & 4.0 & 4.0 & 4.0 & 4.0 \\
\hline Limestone & 1.60 & 1.30 & 1.30 & 1.60 & 1.60 \\
\hline Fine ground corn & 1.38 & 2.10 & 2.08 & 0.46 & 0.34 \\
\hline Urea & --- & --- & --- & 1.15 & 1.27 \\
\hline Salt & 0.30 & 0.30 & 0.30 & 0.30 & 0.30 \\
\hline Potassium chloride & 0.53 & 0.11 & 0.13 & 0.30 & 0.30 \\
\hline Molasses & 0.10 & 0.10 & 0.10 & 0.10 & 0.10 \\
\hline Beef trace mineral $^{3}$ & 0.05 & 0.05 & 0.05 & 0.05 & 0.05 \\
\hline Rumensin- $80^{4}$ & 0.02 & 0.02 & 0.02 & 0.02 & 0.02 \\
\hline Tylan- $40^{5}$ & 0.01 & 0.01 & 0.01 & 0.01 & 0.01 \\
\hline Vitamin A-D-E ${ }^{6}$ & 0.01 & 0.01 & 0.01 & 0.01 & 0.01 \\
\hline \multicolumn{6}{|l|}{ Nutrient Analysis ${ }^{7}$} \\
\hline $\mathrm{CP}, \%$ & 17.87 & 17.87 & 17.87 & 12.50 & 12.50 \\
\hline NDF from byproduct, $\%$ & 22.61 & 22.61 & 22.61 & 0.00 & 0.00 \\
\hline Ether extract, \% & 7.19 & 3.23 & 7.19 & 3.93 & 7.19 \\
\hline Calcium, \% & 0.70 & 0.70 & 0.70 & 0.70 & 0.70 \\
\hline Phosphorus, \% & 0.50 & 0.47 & 0.45 & 0.29 & 0.28 \\
\hline Potassium, \% & 0.70 & 0.70 & 0.70 & 0.70 & 0.70 \\
\hline Sulfur, \% & 0.36 & 0.20 & 0.19 & 0.16 & 0.15 \\
\hline
\end{tabular}

${ }^{1}$ WDGS = wet distillers grains plus solubles (WDGS) diet, $\mathrm{COMP}=$ composite diet, $\mathrm{COMP}+$ $\mathrm{OIL}=$ composite + corn oil diet, $\mathrm{CON}=$ control diet, $\mathrm{CON}+\mathrm{OIL}=$ control + corn oil diet.

${ }^{2}$ Supplement formulated to be fed at $4 \%$ of diet DM.

${ }^{3}$ Premix contained $10 \% \mathrm{Mg}, 6 \% \mathrm{Zn}, 4.5 \% \mathrm{Fe}, 2 \% \mathrm{Mn}, 0.5 \% \mathrm{Cu}, 0.3 \% \mathrm{I}, 0.05 \% \mathrm{Co}$.

${ }^{4}$ Premix contained $176 \mathrm{~g}$ monensin/kg.

${ }^{5}$ Premix contained $88 \mathrm{~g}$ tylosin $/ \mathrm{kg}$.

${ }^{6}$ Premix contained 1,500 IU vitamin A, 3,000 IU vitamin D, 3.7 IU vitamin E per g.

${ }^{7}$ Nutrient analyses calculated for each individual ingredient multiplied by corresponding dietary inclusion. Ether extract was measured whereas the other nutrients are based on formulation. 
Table 4. Animal performance and carcass characteristics for different distillers grains and corn oil diets for individually fed heifers (Exp. 1)

\begin{tabular}{|c|c|c|c|c|c|c|c|c|c|c|c|c|c|c|}
\hline \multirow[b]{2}{*}{ Item } & \multicolumn{6}{|c|}{ Treatment $^{1}$} & \multirow[b]{2}{*}{ SEM } & \multicolumn{7}{|c|}{$P$-value ${ }^{2}$} \\
\hline & OFAT & 2.5FAT & 5FAT & ODG & 20DG & 40DG & & Cov & Int & $\mathbf{S}$ & Lin & Quad & $\begin{array}{l}\text { Fat- } \\
\text { lin }\end{array}$ & $\begin{array}{l}\text { DG- } \\
\text { lin }\end{array}$ \\
\hline \multicolumn{15}{|c|}{ Animal Performance and Diet Energy } \\
\hline Initial BW, kg & 353 & 352 & 345 & 343 & 352 & 342 & 8 & $<0.01$ & 0.86 & 0.47 & 0.70 & 0.40 & --- & --- \\
\hline Final BW, $\mathrm{kg}^{3}$ & 509 & 508 & 474 & 498 & 508 & 506 & 14 & $<0.01$ & 0.31 & 0.52 & 0.36 & 0.38 & --- & --- \\
\hline DMI, kg/d & 9.1 & 9.1 & 8.2 & 9.0 & 9.1 & 8.9 & 0.4 & 0.51 & 0.50 & 0.51 & 0.13 & 0.47 & --- & --- \\
\hline $\mathrm{ADG}, \mathrm{kg} / \mathrm{d}$ & 1.38 & 1.37 & 1.13 & 1.38 & 1.38 & 1.45 & 0.8 & 0.24 & 0.09 & --- & --- & --- & 0.04 & 0.53 \\
\hline $\mathrm{G}: \mathrm{F}, \mathrm{kg} / \mathrm{kg}$ & 0.151 & 0.152 & 0.136 & 0.154 & 0.155 & 0.163 & 0.006 & 0.05 & 0.10 & --- & $\begin{array}{ll}-- \\
-\end{array}$ & --- & 0.10 & 0.27 \\
\hline Diet $\mathrm{NE}_{\mathrm{g}}^{4}, \mathrm{Mcal} / \mathrm{kg}$ & 1.34 & 1.35 & 1.24 & 1.33 & 1.37 & 1.42 & 0.05 & 0.54 & 0.16 & 0.15 & 0.93 & 0.61 & --- & --- \\
\hline \multicolumn{15}{|c|}{ Carcass Characteristics } \\
\hline $\mathrm{HCW}, \mathrm{kg}$ & 315 & 314 & 294 & 309 & 315 & 313 & 9 & $<0.01$ & 0.31 & 0.52 & 0.36 & 0.38 & --- & --- \\
\hline Fat thickness, cm & 1.37 & 1.57 & 1.17 & 1.15 & 1.48 & 1.52 & 0.16 & 0.03 & 0.20 & 0.91 & 0.61 & 0.14 & --- & $\begin{array}{ll}-- \\
--\end{array}$ \\
\hline Marbling score $^{5}$ & 526 & 506 & 495 & 551 & 529 & 534 & 16 & 0.09 & 0.88 & 0.04 & 0.15 & 0.56 & --- & --- \\
\hline Yield grade & 2.45 & 2.65 & 2.55 & 2.48 & 2.81 & 2.89 & 0.24 & 0.51 & 0.82 & 0.37 & 0.30 & 0.53 & --- & --- \\
\hline $\mathrm{LM}$ area, $\mathrm{cm}^{2}$ & 76.8 & 75.6 & 72.9 & 74.8 & 76.1 & 74.5 & 2.7 & $<0.01$ & 0.80 & 0.99 & 0.44 & 0.64 & --- & --- \\
\hline
\end{tabular}

${ }^{1} \mathrm{OFAT}=0 \%$ corn oil diet, $2.5 \mathrm{FAT}=2.5 \%$ corn oil diet, $5 \mathrm{FAT}=5.0 \%$ corn oil diet, $0 \mathrm{DG}=0 \%$ wet distillers grains plus solubles (WDGS) diet, $20 \mathrm{DG}=20 \%$ WDGS diet, $40 \mathrm{DG}=40 \%$ WDGS diet.

${ }^{2} \mathrm{Cov}=$ covariate, Int $=$ source $\times$ level interaction, $\mathrm{S}=$ main effect of source, Lin $=$ linear effect of level, Quad $=$ quadratic effect of level, Fat-lin = linear effect of added fat, DG-lin = linear effect of WDGS level.

${ }^{3}$ Calculated from $\mathrm{HCW}$, adjusted to a $62 \%$ common yield.

${ }^{4}$ Based on cattle performance (NRC, 1996).

${ }^{5} 400=$ Slight $0,500=$ Small 0. 
Table 5. Animal performance and carcass characteristics of finishing steers fed dried distillers grains plus solubles (DDGS) or tallow (Exp. 2)

\begin{tabular}{|c|c|c|c|c|c|c|c|c|c|}
\hline & \multicolumn{5}{|c|}{ Treatment $^{1}$} & & \multicolumn{3}{|c|}{$P$-value ${ }^{2}$} \\
\hline Item & $\mathrm{CON}$ & 1.3TAL & 2.6TAL & 20DG & 40DG & $\mathbf{S E}$ & $F$-test & Tal-lin & DG-lin \\
\hline \multicolumn{10}{|c|}{ Animal Performance and Diet Energy } \\
\hline Initial BW, kg & 351 & 351 & 351 & 352 & 352 & 1 & 0.89 & 0.93 & 0.56 \\
\hline Final BW, $\mathrm{kg}^{3}$ & 617 & 613 & 622 & 617 & 624 & 5 & 0.55 & 0.44 & 0.25 \\
\hline DMI, kg/d & 12.3 & 12.1 & 12.3 & 12.3 & 12.3 & 0.2 & 0.91 & 0.94 & 0.99 \\
\hline $\mathrm{ADG}, \mathrm{kg} / \mathrm{d}$ & 2.24 & 2.21 & 2.29 & 2.24 & 2.31 & 0.05 & 0.59 & 0.42 & 0.29 \\
\hline $\mathrm{G}: \mathrm{F}, \mathrm{kg} / \mathrm{kg}$ & 0.183 & 0.183 & 0.187 & 0.183 & 0.188 & 0.003 & 0.56 & 0.36 & 0.20 \\
\hline \multicolumn{10}{|c|}{ Carcass Characteristics } \\
\hline $\mathrm{HCW}, \mathrm{kg}$ & 389 & 386 & 392 & 389 & 393 & 3 & 0.54 & 0.43 & 0.24 \\
\hline Fat thickness, cm & 1.47 & 1.55 & 1.45 & 1.30 & 1.55 & 0.08 & 0.18 & 0.68 & 0.51 \\
\hline Marbling score, ${ }^{5}$ & 541 & 532 & 542 & 527 & 537 & 13 & 0.88 & 0.95 & 0.79 \\
\hline
\end{tabular}

${ }^{1} \mathrm{CON}=$ control diet, $1.3 \mathrm{TAL}=1.3 \%$ tallow, $2.6 \mathrm{TAL}=2.6 \%$ tallow diet, 20DG $=20 \%$ DDGS diet, $40 \mathrm{DG}=40 \% \mathrm{DDGS}$ diet.

${ }^{2}$ F-test $=$ overall $F$-test representing variation due to treatment, Tal-lin $=$ linear effect of tallow, and DG-lin $=$ linear effect of DDGS.

${ }^{3}$ Calculated from $\mathrm{HCW}$, adjusted to a $63 \%$ common dress.

${ }_{5}^{4}$ Based on cattle performance (NRC, 1996).

${ }^{5} 400=$ Slight $0,500=$ Small 0.

${ }^{6} \mathrm{~A}-=1, \mathrm{~A}=2, \mathrm{~A}+=3$. 
Table 6. Ruminal pH variables and VFA profiles of steers fed wet distillers grains plus solubles (WDGS), a composite, or supplemental corn oil (Exp. 3)

\begin{tabular}{|c|c|c|c|c|c|c|c|}
\hline & & & Treatment & & & & \\
\hline Item & WDGS & COMP & COMP + OIL & $\mathrm{CON}$ & $\mathrm{CON}+\mathrm{OIL}$ & SEM & F-test $^{2}$ \\
\hline Ruminal pH variables & & & & & & & \\
\hline Average $\mathrm{pH}$ & $5.24^{b}$ & $5.40^{b}$ & $5.66^{\mathrm{a}}$ & $5.37^{b}$ & $5.38^{b}$ & 0.10 & 0.08 \\
\hline Maximum $\mathrm{pH}$ & 5.77 & 6.06 & 6.30 & 5.91 & 5.92 & 0.15 & 0.16 \\
\hline Minimum $\mathrm{pH}$ & 4.95 & 4.90 & 5.09 & 4.88 & 5.00 & 0.08 & 0.42 \\
\hline $\mathrm{pH}$ change & 0.82 & 1.16 & 1.21 & 1.02 & 0.91 & 0.11 & 0.13 \\
\hline Time $<5.6, \mathrm{~min} / \mathrm{d}$ & $1251^{\mathrm{a}}$ & $1047^{\mathrm{a}}$ & $652^{b}$ & $1136^{\mathrm{a}}$ & $1050^{\mathrm{a}}$ & 123 & 0.03 \\
\hline Time $<5.3, \mathrm{~min} / \mathrm{d}$ & 916 & 515 & 166 & 630 & 634 & 184 & 0.12 \\
\hline Time $<5.0, \mathrm{~min} / \mathrm{d}$ & 242 & 186 & 17 & 81 & 157 & 105 & 0.59 \\
\hline VFA, mol/100 mol & & & & & & & \\
\hline Acetate & $41.9^{b}$ & $48.8^{\mathrm{a}}$ & $49.3^{a}$ & $48.2^{a}$ & $49.1^{\mathrm{a}}$ & 3.0 & 0.04 \\
\hline Propionate & $40.0^{\mathrm{a}}$ & $36.6^{b}$ & $34.8^{b}$ & $36.7^{b}$ & $34.7^{b}$ & 3.0 & 0.06 \\
\hline Butyrate & 12.7 & 8.5 & 9.7 & 10.7 & 12.8 & 1.5 & 0.20 \\
\hline Acetate:propionate & $1.05^{b}$ & $1.33^{\mathrm{a}}$ & $1.42^{\mathrm{a}}$ & $1.31^{\mathrm{a}}$ & $1.41^{\mathrm{a}}$ & 0.3 & 0.04 \\
\hline
\end{tabular}

${ }^{1}$ WDGS = wet distillers grains plus solubles (WDGS) diet, COMP = composite diet, COMP + OIL = composite + corn oil diet, CON $=$ control diet, $\mathrm{CON}+\mathrm{OIL}=$ control + corn oil diet .

${ }^{2}$ Data were analyzed using a protected F-test where numbers represent $P$-value for variation due to treatment.

${ }^{\mathrm{a}, \mathrm{b}}$ Means within a row with unlike superscripts differ $(P<0.10)$. 
Table 7. Influence of wet distillers grains plus solubles (WDGS), a composite, or supplemental corn oil on characteristics of ruminal and total-tract digestion (Exp. 3)

\begin{tabular}{|c|c|c|c|c|c|c|c|}
\hline \multirow[b]{2}{*}{ Item } & & \multicolumn{4}{|c|}{ Treatment $^{1}$} & \multirow[b]{2}{*}{ SEM } & \multirow[b]{2}{*}{ F-test ${ }^{2}$} \\
\hline & WDGS & COMP & COMP + OIL & CON & CON + OIL & & \\
\hline \multicolumn{8}{|l|}{ Intake, $\mathrm{kg} / \mathrm{d}$} \\
\hline DM & $7.8^{\mathrm{a}}$ & $8.3^{\mathrm{a}}$ & $8.8^{\mathrm{a}}$ & $7.9^{\mathrm{a}}$ & $6.1^{\mathrm{b}}$ & 0.7 & 0.06 \\
\hline $\mathrm{OM}$ & $7.4^{\mathrm{a}}$ & $8.0^{\mathrm{a}}$ & $8.5^{\mathrm{a}}$ & $7.5^{\mathrm{a}}$ & $5.7^{\mathrm{b}}$ & 0.6 & 0.05 \\
\hline NDF & $2.3^{\mathrm{b}}$ & $3.0^{\mathrm{a}}$ & $3.2^{\mathrm{a}}$ & $1.4^{\mathrm{c}}$ & $1.0^{\mathrm{c}}$ & 0.2 & $<0.01$ \\
\hline $\mathrm{N}$ & $0.20^{\mathrm{a}}$ & $0.18^{\mathrm{a}}$ & $0.20^{\mathrm{a}}$ & $0.14^{\mathrm{b}}$ & $0.11^{\mathrm{b}}$ & 0.02 & $<0.01$ \\
\hline Starch & $3.3^{\mathrm{b}}$ & $3.4^{\mathrm{b}}$ & $3.4^{\mathrm{b}}$ & $5.2^{\mathrm{a}}$ & $3.8^{\mathrm{b}}$ & 0.2 & $<0.01$ \\
\hline Fat & $0.68^{\mathrm{a}}$ & $0.38^{\mathrm{c}}$ & $0.76^{\mathrm{a}}$ & $0.41^{b c}$ & $0.53^{\mathrm{b}}$ & 0.06 & $<0.01$ \\
\hline \multicolumn{8}{|c|}{ Ruminal digestibility, \% } \\
\hline Apparent OM & 43.6 & 42.3 & 39.0 & 47.0 & 41.3 & 5.7 & 0.89 \\
\hline True $\mathrm{OM}^{3}$ & 64.1 & 60.1 & 58.4 & 63.4 & 58.2 & 4.8 & 0.84 \\
\hline NDF & 71.0 & 52.0 & 55.6 & 56.2 & 60.1 & 6.0 & 0.25 \\
\hline Apparent starch & $79.5^{\mathrm{a}}$ & $84.7^{\mathrm{a}}$ & $76.6^{\mathrm{a}}$ & $76.6^{\mathrm{a}}$ & $62.1^{\mathrm{b}}$ & 5.5 & 0.03 \\
\hline True starch ${ }^{4}$ & $83.8^{\mathrm{a}}$ & $87.9^{\mathrm{a}}$ & $85.9^{\mathrm{a}}$ & $81.5^{\mathrm{a}}$ & $70.0^{b}$ & 4.3 & 0.03 \\
\hline \multicolumn{8}{|c|}{$\begin{array}{l}\text { Postruminal digestibility, \% } \\
\text { entering }\end{array}$} \\
\hline $\mathrm{OM}$ & 48.0 & 38.1 & 33.5 & 51.1 & 52.2 & 6.9 & 0.24 \\
\hline NDF & $34.5^{\mathrm{ab}}$ & $48.5^{\mathrm{a}}$ & $19.1^{b}$ & $47.4^{\mathrm{a}}$ & $44.1^{\mathrm{ab}}$ & 9.1 & 0.08 \\
\hline Starch & $70.8^{\mathrm{a}}$ & $52.6^{\mathrm{bc}}$ & $39.7^{b}$ & $56.7^{\mathrm{ac}}$ & $72.2^{\mathrm{a}}$ & 7.4 & 0.04 \\
\hline \multicolumn{8}{|c|}{ Total-tract digestibility, $\%$} \\
\hline $\mathrm{DM}$ & $81.0^{\mathrm{a}}$ & $74.5^{b}$ & $71.1^{\mathrm{b}}$ & $81.6^{\mathrm{a}}$ & $80.3^{\mathrm{a}}$ & 1.7 & $<0.01$ \\
\hline $\mathrm{OM}$ & $82.5^{\mathrm{a}}$ & $75.8^{\mathrm{b}}$ & $72.2^{b}$ & $82.2^{\mathrm{a}}$ & $82.4^{\mathrm{a}}$ & 1.8 & $<0.01$ \\
\hline $\mathrm{NDF}$ & $78.9^{\mathrm{a}}$ & $65.9^{\mathrm{b}}$ & $64.5^{b}$ & $78.2^{\mathrm{a}}$ & $78.8^{\mathrm{a}}$ & 3.2 & $<0.01$ \\
\hline Starch & $94.6^{\mathrm{a}}$ & $91.7^{\mathrm{ab}}$ & $90.6^{b}$ & $92.2^{\mathrm{ab}}$ & $89.0^{\mathrm{b}}$ & 1.7 & 0.10 \\
\hline Fat & $81.0^{\mathrm{a}}$ & $64.1^{\mathrm{c}}$ & $67.6^{\mathrm{bc}}$ & $72.5^{b}$ & $72.8^{\mathrm{b}}$ & 3.7 & $<0.01$ \\
\hline
\end{tabular}

${ }^{1}$ WDGS = wet distillers grains plus solubles (WDGS) diet, $\mathrm{COMP}=$ composite diet, $\mathrm{COMP}+$ $\mathrm{OIL}=$ composite + corn oil diet, $\mathrm{CON}=$ control diet, $\mathrm{CON}+\mathrm{OIL}=$ control + corn oil diet.

${ }^{2}$ Data were analyzed using a protected F-test where numbers represent $P$ - value for variation due to treatment.

${ }^{3}$ Corrected for microbial OM reaching the duodenum.

${ }^{4}$ Corrected for microbial starch.

${ }^{\mathrm{a}, \mathrm{b}, \mathrm{c}}$ Means within a row not bearing a common superscript differ $(P<0.10)$. 
Table 8. Fatty acid profiles (g/100 g fatty acids) of duodenal fat content of steers fed wet distillers grains plus solubles (WDGS), a composite, or supplemental corn oil (Exp. 3)

\begin{tabular}{|c|c|c|c|c|c|c|c|}
\hline & \multicolumn{5}{|c|}{ Treatment $^{1}$} & \multicolumn{2}{|l|}{ 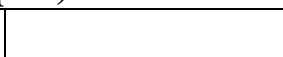 } \\
\hline Fatty acid & WDGS & COMP & COMP +OIL & CON & $\mathrm{CON}+\mathrm{OIL}$ & SEM & F-test ${ }^{2}$ \\
\hline $14: 0$ & $0.92^{b c}$ & $1.14^{\mathrm{b}}$ & $0.76^{\mathrm{c}}$ & $2.07^{\mathrm{a}}$ & $0.89^{b c}$ & 0.22 & $<0.01$ \\
\hline $15: 0$ & $0.46^{\mathrm{c}}$ & $0.69^{b}$ & $0.46^{\mathrm{c}}$ & $1.15^{\mathrm{a}}$ & $0.46^{b c}$ & 0.08 & $<0.01$ \\
\hline $16: 0$ & $13.80^{\mathrm{a}}$ & $12.55^{b c}$ & $12.28^{b}$ & $13.41^{\mathrm{ac}}$ & $12.52^{b c}$ & 0.37 & 0.04 \\
\hline 16:1 trans & $0.12^{b}$ & $0.28^{\mathrm{a}}$ & $0.15^{b}$ & $0.15^{b}$ & $0.15^{b}$ & 0.03 & 0.04 \\
\hline $17: 0$ & $0.34^{\mathrm{b}}$ & $0.62^{\mathrm{a}}$ & $0.37^{b}$ & $0.56^{\mathrm{a}}$ & $0.33^{b}$ & 0.05 & $<0.01$ \\
\hline 18:0 & $48.5^{c}$ & $55.0^{b}$ & $62.1^{a}$ & $56.1^{b}$ & $60.5^{a}$ & 1.4 & $<0.01$ \\
\hline 18:1 trans & $12.6^{\mathrm{a}}$ & $9.0^{b}$ & $7.4^{\mathrm{c}}$ & $5.9^{c}$ & $7.1^{\mathrm{c}}$ & 0.7 & $<0.01$ \\
\hline $18: 1$ & $9.4^{\mathrm{a}}$ & $6.6^{b c}$ & $5.8^{b}$ & $7.0^{\mathrm{c}}$ & $6.5^{b c}$ & 0.4 & $<0.01$ \\
\hline $18: 2$ & $8.5^{\mathrm{a}}$ & $5.9^{b}$ & $4.9^{b c}$ & $4.9^{b c}$ & $4.4^{\mathrm{c}}$ & 0.5 & $<0.01$ \\
\hline $18: 3$ & $0.29^{\mathrm{a}}$ & $0.28^{\mathrm{a}}$ & $0.19^{b}$ & $0.23^{\mathrm{ab}}$ & $0.20^{b}$ & 0.05 & 0.04 \\
\hline Other & $5.3^{b}$ & $7.0^{\mathrm{a}}$ & $5.2^{b}$ & $8.0^{\mathrm{a}}$ & $6.0^{b}$ & 0.5 & $<0.01$ \\
\hline
\end{tabular}

${ }^{1}$ WDGS = wet distillers grains plus solubles (WDGS) diet, COMP = composite diet, COMP + $\mathrm{OIL}=$ composite + corn oil diet, $\mathrm{CON}=$ control diet, $\mathrm{CON}+\mathrm{OIL}=$ control + corn oil diet.

${ }^{2}$ Data were analyzed using a protected $F$-test where numbers represent $P$ - value for variation due to treatment.

${ }^{\mathrm{a}, \mathrm{b}, \mathrm{c}}$ Means within a row not bearing a common superscript differ $(P<0.10)$. 